\title{
Effects of Moringa oleifera Aqueous Leaf Extract on Some Serum-biochemical Constituents on Wister Rats
}

\author{
Ibrahim Maina Hassan ${ }^{1}$, Bashir Saidu ${ }^{1}$, Ja'afaru Abdullahi Ishaq $^{1}$, Ashiru Dahiru ${ }^{1}$, \\ Nafisat Abdulazeez ${ }^{1}$, Halima Ibrahim Yusuf ${ }^{1}$, Jubril Saidu Fatima ${ }^{1}$, Yushau Shuaibu Baraya ${ }^{2}$, \\ Adamu Abdul Abubakar ${ }^{3}$, Adama Musa Abdullahi ${ }^{4}$ \\ ${ }^{1}$ Department of Veterinary Physiology and Biochemistry, Faculty of Veterinary Medicine, Usmanu Danfodiyo University Sokoto, Sokoto, \\ Nigeria \\ ${ }^{2}$ Department of Veterinary Pathology, Faculty of Veterinary Medicine, Usmanu Danfodiyo University Sokoto, Sokoto, Nigeria \\ ${ }^{3}$ Department of Veterinary Surgery and Radiology, Faculty of Veterinary Medicine, Usmanu Danfodiyo University Sokoto, Sokoto, Nigeria \\ ${ }^{4}$ Department of Veterinary Teaching Hospital, Faculty of Veterinary Medicine, University of Maiduguri, Maiduguri, Nigeria
}

Email address:

Ibrahim.hassan@udusok.edu.ng.(I.M.Hassan)

\section{To cite this article:}

Ibrahim Maina Hassan, Bashir Saidu, Ja'afaru Abdullahi Ishaq, Ashiru Dahiru, Nafisat Abdulazeez, Halima Ibrahim Yusuf, Jubril Saidu Fatima, Yushau Shuaibu Baraya, Adamu Abdul Abubakar, Adama Musa Abdullahi. Effects of Moringa oleifera Aqueous Leaf Extract on Some Serum-biochemical Constituents on Wister Rats. American Journal of Life Sciences. Vol. 8, No. 5, 2020 , pp. 96-101. doi: 10.11648/j.ajls.20200805.12

Received: April 2, 2020; Accepted: May 18, 2020; Published: August 27, 2020

\begin{abstract}
Medicinal plants have been used in healthcare since time immemorial. Studies have been carried out globally to verify their efficacy and some of the findings have led to the production of plant-based medicines. The global market value of medicinal plant products exceeds $\$ 100$ billion per annum. This study was conducted to know the effect of Moringa oleifera leaf on Serum biochemistry of experimental exposed Wister rats. Moringa oleifera leaf was extracted with distilled water and concentrated to semisolid form with rotary evaporator at $42^{\circ} \mathrm{C}$. Twenty apparently healthy rats weighing $128-233 \mathrm{~g}$ were exposed to different concentration of Moringa oleifera aqueous leaf extract. Control group were exposed to only distill water. The animals were divided into 3 groups of five rats each, with Group-I exposed to $500 \mathrm{mg} / \mathrm{kg}$ crude extract. Group-II exposed to $1000 \mathrm{mg} / \mathrm{kg}$ crude extract and Group-III exposed to $2000 \mathrm{mg} / \mathrm{kg}$ crude extract. There significant difference ( $<<0.05$ ) in analyzed serum biochemical parameters (Creatinine, Urea, Aspartate amino transferase and Alanine amino transferase) between the experimental and control group. From this finding, it can be concluded that Moringa oleifera leaf extract up to $2000 \mathrm{mg} / \mathrm{kg}$ is safe and cause slight changes in serum biochemistry. Toxicity studies of this plant extracts as well as phytochemical studies to reaffirm it effect in several body tissues and organs and identify the bioactive compounds are highly recommended.
\end{abstract}

Keywords: Alanine Amino Transferase, Aqueous, Aspartate Amino Transferase, Concentration, Creatinine, Moringa oleifera, Urea

\section{Introduction}

Moringa oleifera Lamarack is a species of the genus Moringa belonging to the family Moringacea, it is an important food commodity which has had enormous attention as the 'natural nutrients in tropics [1]. In many countries, particularly India, Pakistan, Philippines, Hawaii and many parts of Africa the leaf, fruit, flowers and immature pods of this tree are used as vegetable due to it highly nutritive value.
Supplementation with Moringa seeds, leaf or their extract has several health benefits as reported [2]. Moringa root, wood lower the deposition of stone forming constituents in the kidneys of calculogenic rats and reduced the elevated urinary oxalate as a result of ethylene glycol treatment [3]. Moringa ameliorated liver fibrosis in rats, reduces liver damage, reverse the symptoms of liver fibrosis as well as decreased the $\mathrm{CCl}_{4}{ }^{-}$ induced elevation of serum aminotransferase activities and globulin level. Its also reduced the elevated hepatic 
hydroxyproline content and myeloperoxidase activity [4]. The leaf of the plant act as a good source of natural antioxidants and thus enhance the shelf-life of fat containing foods due to the presence of various antioxidant bioactive compounds such as ascorbic acid, flavonoids, phenolics and carotenoids and been reported to be a rich source of $\beta$-carotene, protein, vitamin $C$, calcium and potassium [5]. The nutraceutical uses of this plant, its potential in treatment of hyperglycemia as well as hypercholesterolemia and also it nutritional values as supplement lead to it prescription as food appendage for patients with coronary artery disease [6]. Reports on antidiabetic and antioxidant activity of aqueous extract of moringa leaf, shows high potential benefits especially on streptozotocin induced diabetic in albino rats [7].

Rat refers to a wide variety of small animals of the family Rodentia. Report shows that the animals originate as natural habitat of steppes Asia, but at some point in the 1600s, conditions changed and they became commensally with man, spreading throughout the world [8]. These animals are characterized with coarse fur in dull colors such as brown and black, powerful incisors and hairless tails, they can gnaw through hard materials using their incisors. Most rats Rattus norvegicus (Wister) seen in private practice and used in laboratories setting today are domesticated and originated from Norway. Rats made their initial appearance as laboratory animals, In the $1850 \mathrm{~s}$. Norway rats are widely regarded as the first species to be domesticated for scientific purposes [9]. Serum biochemistry refers to the chemical analysis of serum. There are many substances in serum, including proteins, enzymes, lipids, hormones etc. Testing for these various substances provides information about the organs and tissues in the body as well as the metabolic state of the animal. If a test result is abnormal, it may indicate that disease is present [10]. Hence, the aim and objectives of this study is to evaluate the effect of graded doses of Moringa oleifera aqueous leaf extract on some serum biochemistry parameters in Wister rats by measuring the urea, creatinine, aspartate amino transferase (AST) and alanine amino transferase (ALT) in both experimental exposed and control groups.

\section{Methodology}

\subsection{Plant Collection and Identification}

Fresh leaf of Moringa oleifera found around Sokoto State Central Market was collected. The plant's leaf was identified and authenticated at the botany unit of Department of Biological Sciences in Usmanu Danfodiyo University, Sokoto, Nigeria.

\subsection{Plant Preparation}

The leaf was prepared according to the procedure described by Huang et al., 2017 [11]. Briefly, the procedure involved drying the leaf in the laboratory to constant weight at room temperature. The leaf was then washed and grounded to semi powdered form using an electric blender. $5 \mathrm{~g}$ of the extract was mixed with $50 \mathrm{~mL}$ distilled water. The prepared solution was left to stand for two days and then filtered using muslin cloth.

\subsection{Experimental Animals}

Twenty apparently healthy rats both sexes weighing 128$233 \mathrm{~g}$ were obtained and used in this study. The rats were acclimatized for 2 weeks $\left(25-27^{\circ} \mathrm{C}\right)$ at Veterinary biochemistry research laboratory Usmanu Danfodiyo University Sokoto. The rats were randomly divided into four groups of five rats per group as shown below. They were fed with commercial feed from vita company Nigeria and water was given to them adlibitum.

Group-I - Five rats administered with $500 \mathrm{mg} / \mathrm{kg}$ of Moringa oleifera aqueous leaf extract. Group-II - Five rats administered with $1000 \mathrm{mg} / \mathrm{kg}$ of Moringa oleifera aqueous leaf extract. Group-III - Five rats administered with 2000 $\mathrm{mg} / \mathrm{kg}$ of Moringa oleifera aqueous leaf extract.

Control group consist of rats administered only distilled water

At the end of the exposure, animals were euthanized using inhation anesthesia (chloroform), vital parameters were observed as well as response to stimuli (such as pinching the toe) to ascertain effective euthanization. A $5 \mathrm{ml}$ syringe with a 23 gauge needle was prepared, rats were then placed on their back and left index finger was placed at the level of the lower ribs to locate the heart. The needle was then inserted at an angle of $45^{\circ}$ and blood was collected into the syringe. The syringe was carefully remove and disconnect from the needle and empty into the plain sample bottle after collection.

\subsection{Determination of Serum Creatinine}

Reagents used include Picric acid (10mM), Sodium borate (10 mM), Sodium hydroxide and surfactant (240 mM), Creatinine standard $(5.0 \mathrm{mg} / \mathrm{dl})$. Principally, creatinine reacts with picric acid in alkaline buffer and form complex color that was measured with spectrophotometer at $510 \mathrm{~nm}$. A $3.0 \mathrm{~cm}^{3}$ of working reagent was added into test tubes followed by transferred of $0.1 \mathrm{~cm}^{3}(100 \mu \mathrm{l})$ experimental samples to the respective tubes. The tubes were then placed at $37^{\circ} \mathrm{C}$ using water bath for 15 minutes. Hence, creatinine level was determined spectophotometrically using Randox commercial kit by measuring the optical density of both the experimental and the control samples [12]. Analysis were made by first taken the blank and standardized the reading as control. Absorbance of samples was read at $510 \mathrm{~nm}$ and Creatinine value was then calculated using the formula below. Creatinine value of unknown (sample) was determined by comparing its absorbance change with that of a known standard.

$\mathrm{Mg} / \mathrm{dl}=$ Asample $/$ Astandard $\times$ concentration of standard .

\subsection{Determination of Urea}

Reagents used include ethylene diamine tetra-acetic acid (EDTA) (116 mmol/l), Sodium nitroprusside $(6 \mathrm{mmol} / \mathrm{l})$ and Urease (1 g/l), Phenol (diluted) (120 mmol/l), Sodium hypochlorite (diluted) $(27 \mathrm{mmol} / \mathrm{l})$ and Standard. Principally, Urea in serum is hydrolysed to ammonia in the presence of 
urease and measured with spectophotometer using Berthelot reaction. Samples $(10 \mu \mathrm{L})$ was added to EDTA $(100 \mu \mathrm{L})$, Phenol $(2,50 \mu \mathrm{L})$ and Sodium nitroprusside $(2,50 \mu \mathrm{L})$ working solution and maintained at $37^{\circ} \mathrm{C}$ using water bath for 10 minutes. Hence, Urea level was determined spectophotometrically using Randox commercial kit by measuring the optical density of both the experimental and the control samples [13]. Absorbance of samples was read at $510 \mathrm{~nm}$ and urea concentration was then calculated using the formula below;

\section{Urea Concentration $=$ Asample $/$ Astandard $\times$ Standard concentration $(\mathrm{mmol} / \mathrm{l})$}

\subsection{Determination of Aspartate Aminotransferase (AST)}

Reagents used includes Tris buffer, $\mathrm{pH}$ : 7.80 (88 mmol/L), L-Aspartate $(260 \mathrm{mmol} / \mathrm{L})$, nicotinamide adenine dinucleotide NADH $(0.22 \mathrm{mmol} / \mathrm{L})$, Lactate dehydrogenase LDH (900 U/L), malate dehydrogenase MDH (600 U/L), $\alpha$ Ketoglutarate $12 \mathrm{mmol} / \mathrm{L}$. Determination of aspartate aminotransferase activity in serum was carried out following the method described IFCC 1985 [14]. Preparation and stabilization of the working reagent was carried out by mixing NADH (0.22 mmol/L), LDH (900 U/L), (MDH 600 $\mathrm{U} / \mathrm{L})$ and $\alpha$ - Ketoglutarate $(12 \mathrm{mmol} / \mathrm{L})$ into test tube containing Tris buffer, $\mathrm{pH}$ : $7.80(88 \mathrm{mmol} / \mathrm{L}$ and L-Aspartate $(260 \mathrm{mmol} / \mathrm{L})$ at $37^{\circ} \mathrm{C}$ respectively. Principally, the substrate present in the samples were catalyzed by AST to L-aspartate and oxyglutarate, NADH coenzyme, Malate dehydrogenase $(\mathrm{MDH})$ transformed the intermediate to oxaloacetate. The oxido-reductive process of $\mathrm{NADH} / \mathrm{NAD}^{+}$is observed by decrease in absorbance at $340 \mathrm{~nm}$. Lactate dehydrogenase (LDH) counteracts the effect of pyruvate present in the sample. Working solution $(1 \mathrm{~mL})$ was added to $100 \mu \mathrm{L}$ serum sample of both experimental and control rat mix and incubated for 3 minutes. Measurement of AST was carried out by calculating the differences in absorbance of both experimental sample and references as follow;

\section{$\frac{\text { Changes in sample A } \times \text { concentration of standard }}{\text { Changes in standard }}=$ Concentration sample}

\subsection{Determination of Alanine Amino Transferase (ALT)}

Reagents include, Tris buffer $\mathrm{P}^{\mathrm{H}} 7.15$ at $37^{\circ} \mathrm{C}(100$ $\mathrm{mmol} / \mathrm{L})$, L-Alanine $(500 \mathrm{mmol} / \mathrm{L}), \alpha$ - oxoglutarate $(12$ $\mathrm{mmol} / \mathrm{L})$, LDH $(1.8 \mathrm{kU} / \mathrm{L})$ and NADH $(0.20 \mathrm{mmol} / \mathrm{L})$. Determination of ALT was carried out according to the method reported by [15]. Principally, ALT transfers the amino group from alanine to $\alpha$-oxoglutarate to form pyruvate and glutamate. Preparation and stabilization of the working reagent was carried out by mixing Tris buffer $\mathrm{P}^{\mathrm{H}} 7.15$ at $37^{\circ} \mathrm{C}$ $(100 \mathrm{mmol} / \mathrm{L}), \mathrm{L}-$ Alanine $(500 \mathrm{mmol} / \mathrm{L}), \alpha$ - oxoglutarate $(12$ $\mathrm{mmol} / \mathrm{L}), \mathrm{LDH}(1.8 \mathrm{kU} / \mathrm{L}), \mathrm{NADH}(0.20 \mathrm{mmol} / \mathrm{L})$. Pyruvate is converted to lactate in the present of lactate dehydrogenase (LD) with NADH producing $\mathrm{NAD}^{+}$. Decreased absorbance due to the consumption of NADH was measured at $340 \mathrm{~nm}$ with the aid of spectrophotometer. Concentration of ALT was calculated with the formula below:

\section{$\frac{\text { Changes in sample } A \times \text { concentration of standard }}{\text { Changes in standard }}=$ Concentration sample}

\subsection{Statistical Analysis}

The data obtained were analyzed using microsoft office Excel 2007 and Statistical Package used was Graph prism version 5.0. Results were expressed as mean \pm SD and presented in tabular form. The result of serum biochemical analysis including creatinine, Urea, AST and ALT obtained from the experimental groups were compared with the of control groups using paired two-tailed student's t-test for matched samples and analysis of variance (ANOVA) was used for comparisons of three (3) or more values of the parameters in the various groups.

\section{Results}

\subsection{Result of Moringa oleifera on Serum Creatinine Level}

Effect of Moringa oleifera on Serum creatinine level in experimentally exposed Wister rats shows increased in serum creatinine level with significant different at $p>0.01$ between the control groups and the groups that were exposed to $2000 \mathrm{mg} / \mathrm{kg}$. There was no significant difference between the control groups and the groups that were exposed to $500 \mathrm{mg} / \mathrm{kg}$ and $1000 \mathrm{mg} / \mathrm{kg}$.
The result also shows no significant different between groups that were exposed to $500 \mathrm{mg} / \mathrm{kg}$ and $1000 \mathrm{mg} / \mathrm{kg}$ as well as the groups exposed to $1000 \mathrm{mg} / \mathrm{kg}$ and $2000 \mathrm{mg} / \mathrm{kg}$. There is significant different at $\mathrm{p}>0.05$ between the groups that were exposed to $500 \mathrm{mg} / \mathrm{kg}$ and $2000 \mathrm{mg} / \mathrm{kg}$ (figure 1).

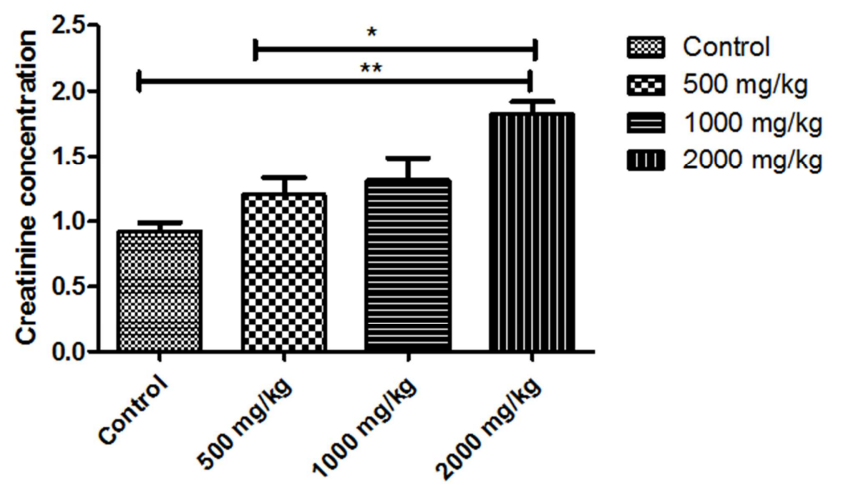

Figure 1. Effect of Moringa oleifera (leaf) extract at different concentration $(500-2000 \mathrm{mg} / \mathrm{mL})$ on serum creatinine level of experimentally exposed Wister rats. The increase in createnine level $(n=3)$ is shown versus concentration of the tested crude extracts and control. The values represent mean $\pm S D$ from two independent experiments. 


\subsection{Result of Moringa oleifera on Serum Urea Level}

Effect of Moringa oleifera on Serum urea level in experimentally exposed Wister rat shows increased in serum urea level with significant different at $p>0.05$ between the controlgroups and the groups that were exposed to 1000 $\mathrm{mg} / \mathrm{kg}$. There was no significant difference between the control groups and the group that were exposed to $500 \mathrm{mg} / \mathrm{kg}$ and $2000 \mathrm{mg} / \mathrm{kg}$. The result also shows significant different at $\mathrm{p}>0.05$ between groups that were exposed to $500 \mathrm{mg} / \mathrm{kg}$ and $2000 \mathrm{mg} / \mathrm{kg}$ (figure 2).

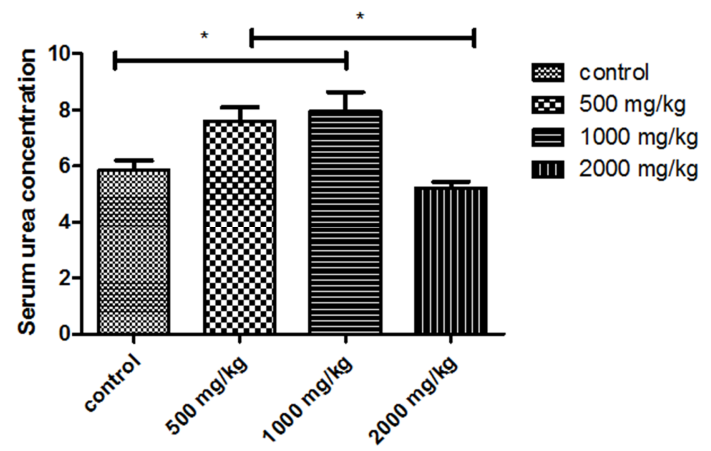

Figure 2. Effect of Moringa oleifera (leaf) extract at different concentration (500-2000 $\mathrm{mg} / \mathrm{mL})$ on serum urea level of experimentally exposed Wister rats. The increase in createnine level $(n=3)$ is shown versus concentration of the tested crude extracts and control. The values represent mean $\pm S D$ from two independent experiments.

\subsection{Result of Moringa oleifera on Serum AST Level}

Effect of Moringa oleifera on Serum AST level in experimentally exposed Wister rat shows increased in serum AST level with significant different at $\mathrm{p}>0.001$ between the control groups and the groups that were exposed to 500 and $1000 \mathrm{mg} / \mathrm{kg}$. There was no significant difference between the control groups and the group that were exposed to 500 $\mathrm{mg} / \mathrm{kg}$. The result also shows significant different at $\mathrm{p}>0.001$ between groups that were exposed to $500 \mathrm{mg} / \mathrm{kg}$ and 2000 $\mathrm{mg} / \mathrm{kg}$. Increase in serum level was also recorded with significant different at $p>0.01$ between groups that were exposed to $500 \mathrm{mg} / \mathrm{kg}$ and the groups that were exposed to $1000 \mathrm{mg} / \mathrm{kg}$ (figure 3).

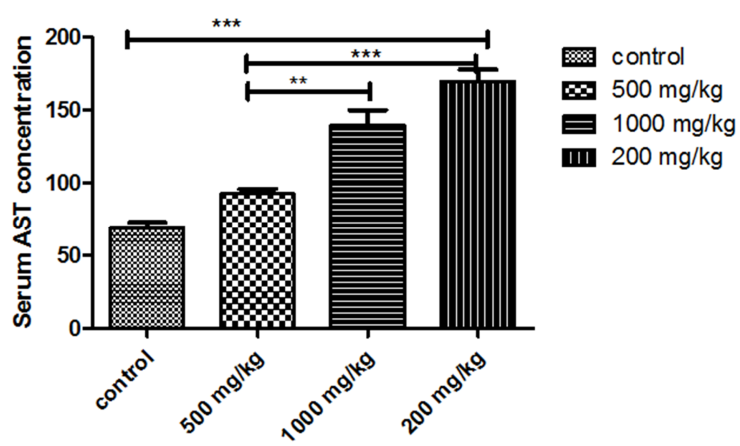

Figure 3. Effect of Moringa oleifera (leaf) extract at different concentration (500-2000 mg/mL) on serum AST level of experimentally exposed Wister rats. The increase in createnine level $(n=3)$ is shown versus concentration of the tested crude extracts and control. The values represent mean $\pm S D$ from two independent experiments.

\subsection{Result of Moringa oleifera on Serum ALT Level}

Effect of Moringa oleifera on Serum ALT level in experimentally exposed Wister rat shows increased in serum ALT level with significant different at $p>0.05$ between the control groups and the groups exposed to $500 \mathrm{mg} / \mathrm{kg}$, as well as different between groups that were exposed to $500 \mathrm{mg} / \mathrm{kg}$ and $2000 \mathrm{mg} / \mathrm{kg}$. There was no significant difference between the groups exposed to $500 \mathrm{mg} / \mathrm{kg}$ and groups exposed to $1000 \mathrm{mg} / \mathrm{kg}$. The result also shows significant different at $\mathrm{p}>$ 0.01 between control groups and groups that were exposed to $1000 \mathrm{mg} / \mathrm{kg}$ as well as between $1000 \mathrm{mg} / \mathrm{kg}$ and $2000 \mathrm{mg} / \mathrm{kg}$ groups respectively.

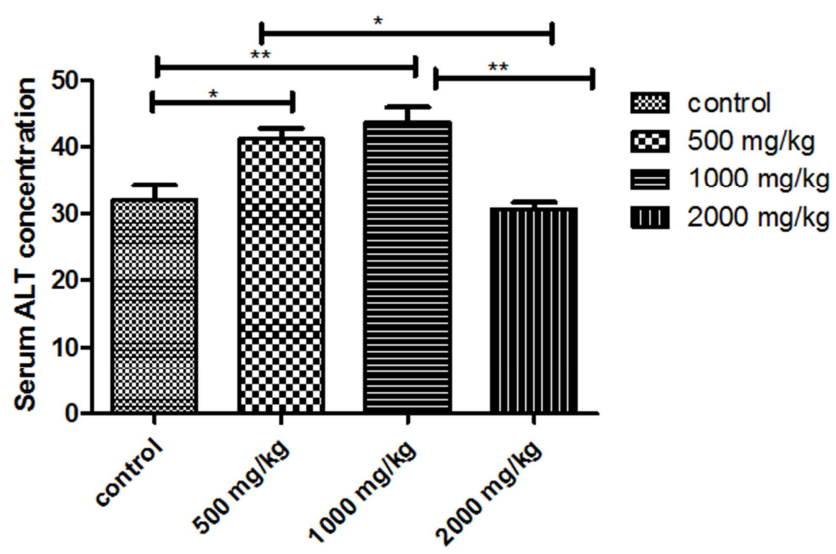

Figure 4. Effect of Moringa oleifera (leaf) extract at different concentration $(500-2000 \mathrm{mg} / \mathrm{mL})$ on serum ALT level of experimentally exposed Wister rats. The increase in createnine level $(n=3)$ is shown versus concentration of the tested crude extracts and control. The values represent mean $\pm S D$ from two independent experiments.

\section{Discussion}

Measurements of serum biochemistry parameter are useful and help in identifying the target organs in toxicity study. General health status of animals and its response to provide early warning of potentially deleterious changes in stressed can also be predicted from the evaluation of the serum biochemistry [16]. It has been reported that $\mathrm{LD}_{50}$ of aqueous leaf extract of Moringa Oleifera was estimated to be 1585 $\mathrm{mg} / \mathrm{kg}$. The daily treatment of aqueous leaf extract of Moringa Oleifera at doses of 250, 500 and $1500 \mathrm{mg} / \mathrm{kg}$ orally for 60 days shows no significance differences in biochemical and hematological parameters in the treated rats when compared with the control groups. Moreover, there was no significant difference in weight gain of the control and treated animals [17]. Investigation of sub-acute oral toxicity of Moringa oleifera extract at dose of 400, 800 and 1600 $\mathrm{mg} / \mathrm{kg}$ on male Wister rats through detection of hematological, biochemical and histological parameters was carried out. The extract at different doses caused significant changes in total RBCs, haemoglobin $(\mathrm{Hb})$, total proteins, liver enzymes, and bilirubin [18]. Sub-lethal treatment of Moringa Oleifera seed extract at dose of $12.40 \mathrm{mg} / \mathrm{L}$ gradually elevated $\mathrm{WBC}$ count, $\mathrm{MCV}, \mathrm{MCH}$, plasma glucose, AST, ALT and ALP activities at the end of 7, 14, 21, 28 and 
$35^{\text {th }}$ days in exposed fish model [19]. The aqueous $M$. Oleifera leaf extract on the serum biochemistry (ALT, AST, Urea, Creatinine) of the Wister rat at the doses used (500 $\mathrm{mg} / \mathrm{kg}, 1000 \mathrm{mg} / \mathrm{kg}$ and $2000 \mathrm{mg} / \mathrm{kg}$ ) did not show obvious change in the animals physically but changes in serum biochemistries were recorded. This suggests aqueous $M$. Oleifera leaf extract at high dose of $2000 \mathrm{mg} / \mathrm{kg}$ may not be severely toxic to cause mortality but can affect the serum biochemistry (ALT, AST, Urea, Creatinine). This is in line with the findings reported by some researchers whose reported significant increase in the liver enzymes following Wister rat exposure to high doses of M. Oleifera seed [20]. Hepato-protective effect of $M$. Oleifera seed extract at doses of $200 \mathrm{mg} / \mathrm{kg}$ and $400 \mathrm{mg} / \mathrm{kg}$ in Wister rats have also been reported. Root of $M$. Oleifera was reported [20]. Some publications also shows that oral administration of the hydro alcoholic leaf extract of $M$. Oleifera (drumstick) increases levels of hepatic enzymes involved in detoxification of xenobiotic substances, carcinogens as well as plant venomous compounds [21]. The findings from this study showed mild adverse effect on the serum biochemistry concentration among the experimentally exposed rats. This is in agreement with the report of [22] who shows mild toxic alteration effect of $M$. Oleifera seed extracts on serum biochemical parameters of Rattus noviegicus.

\section{Conclusion and Recommendations}

In conclusion, this study showed that oral administration of Moringa oleifera aqueous leaf extract at dose up to $2000 \mathrm{mg} / \mathrm{kg}$ is safe and cause but causes changes in serum biochemistry. Toxicity studies of this plant extracts as well as phytochemical studies to reaffirm it effect in several body tissues and organs as well as identifying the bioactive lead compounds are highly recommended.

\section{Declaration of Conflicting Interests}

The author(s) declared no potential conflicts of interest with respect to the research, authorship, and/or publication of this article.

\section{Acknowledgements}

The authors would like to thank all colleague and students of Usmanu Danfodiyo University Sokoto that participated in this study.

\section{References}

[1] Mahmood, K. T., Mugal, T., \& Haq, I. U., Moringa oleifera: a natural gift-A review. Journal of Pharmaceutical Sciences and Research, 2010. 2 (11): p. 775.

[2] Dogra, K. S., Chauhan, S., \& Jalal, J. S., Assessment of Indian medicinal plants for the treatment of asthma Journal of Medicinal Plants Research 2015. 9.(32): p. 851-862.
[3] El Rabey, H. A., Khan, J. A., Sakran, M. I., \& Al-Ghamdi, M. A., The Antioxidant Activity of Low Doses of Moringa Seeds (Moringa oleifera Lam.) in Hypercholesterolemic Male Rats Reactive Oxygen Species 20186 (17): p. 363-370.

[4] Farid, A. S., \& Hegazy, A. M., Ameliorative effects of Moringa oleifera leaf extract on levofloxacin-induced hepatic toxicity in rats Drug and chemical toxicolog 201948 (1): p. 345-55.

[5] Vergara-Jimenez, M., Almatrafi, M. M., \& Fernandez, M. L., Bioactive components in Moringa Oleifera leaves protect against chronic disease. Antioxidants 20176 (4): p. 91.

[6] Nazim, K., Sun, M. C., \& Neergheen-Bhujun, V. S., Perceptions and practices on the use of Moringa oleifera Lam: a qualitative study amongst elderly Mauritians Journal of Complementary and Alternative Medical Research 2017 p. 1-13.

[7] Bamagous, G. A., Al Ghamdi, S. S., Ibrahim, I. A. A., Mahfoz, A. M., Afify, M. A., Alsugoor, M. H \& Rengarajan, T., Antidiabetic and antioxidant activity of ethyl acetate extract fraction of Moringa oleifera leaves in streptozotocin-induced diabetes rats via inhibition of inflammatory mediators. Asian Pacific Journal of Tropical Biomedicine 2018. 8 (6): p. 320.

[8] Pedreschi, D., García - Rodríguez, O., Yannic, G., Cantarello, E., Diaz, A., Golicher, D.,. \& Hardouin, E. A., Challenging the European southern refugium hypothesis: Species - specific structures versus general patterns of genetic diversity and differentiation among small mammals. Global ecology and biogeography, 2019 28.(2): p. 262-274.

[9] Vanhorn, B., Veterinary Guide to Animal Breeds. John Wiley \& Sons., 2017.

[10] Sato, S., Parr, E. B., Devlin, B. L., Hawley, J. A., \& SassoneCorsi, P., Human metabolomics reveal daily variations under nutritional challenges specific to serum and skeletal muscle. Molecular metabolism, 2018 16,: p. 1-11.

[11] Huang, Q., Zhao, W., Yan, A., \& Zhang, W., Applications of Reference Eextract in Determining the Characteristic Spectrum of Ginkgo Leaf Preparations. Herald of Medicine, 2017. 36 (7): p. 794-797.

[12] Rossini, E. L., Milani, M. I., Carrilho, E., Pezza, L., \& Pezza, H. R., Simultaneous determination of renal function biomarkers in urine using a validated paper-based microfluidic analytical device. Analytica chimica acta, 2018 997, p. 16-23.

[13] Rahimi, P., Abedimanesh, S., Mesbah-Namin, S. A., \& Ostadrahimi, A., Betalains, the nature-inspired pigments, in health and diseases. Critical reviews in food science and nutrition, 2019. 59.(18): p. 2949-297.

[14] Oyeyemi, A. O., \& Sonuga, A. A., The Effect of Artemisininbased Combination Therapy (ACT) Antimalaria Drugs on Liver Enzymes in Pregnancy. Journal of Advances in Medical and Pharmaceutical Sciences, 2018 p. 1-6.

[15] Dar, S. A., Nautiyal, V., Phulia, V., Bhat, I. A., Srivastava, P. P., Sahu, N. P., \& Gupta, S., Determination of benzimidazoles in fish plasma by chromatographic method and their effects on metabolic and antioxidative enzymes activity. Aquaculture 2018486 p. 57-63.

[16] Vanmassenhove, J., Kielstein, J., Jörres, A., \& Van Biesen, W., Management of patients at risk of acute kidney injury 2017 The lancet (389): p. 10084. 
[17] Ali, F. R., Elalfy, M. M., Helmy, A. A., \& Elgamal, A. M., Effect of Egyptian Moringa Oleifera Lam. on blood hematology, serum biochemical parameters and lipid profile with special reference to kidney function in albino rats Nat Sci 201715 (9): p. 36-42.

[18] Refaie, A. A. E., Mohafrash, S. M. M., Ibrahim, A. W., \& Mossa, A. T. H., Sub-Acute 28-Days Oral Toxicity Study of Deltamethrin on Female Rats and the Protective Role of Moringa Tea Trends Appl Sci Res 201712 (2): p. 10-17.

[19] Hamed, H. S., \& El-Sayed, Y. S., Antioxidant activities of Moringa oleifera leaf extract against pendimethalin-induced oxidative stress and genotoxicity in Nile tilapia, Oreochromis niloticus (L.). Fish physiology and biochemistry 201945 (1): p. 71-82.
[20] Gabal, A., Khalil, F., Fattah, A. E., Hanaa, M., \& Barakat, H. A., Comparative Study of Water and Oil Extracts of Moringa (Moringa oleifera) Leaves on Immune Response and Hepatic Oxidative Status in Rats. Journal of Scientific Research in Science 201734 (1): p. 641-660.

[21] Kou, X., Li, B., Olayanju, J. B., Drake, J. M., \& Chen, N., Nutracentical or pharmacological potential of Moringa oleifera Lam. Nutrients 10, 20183 (343).

[22] Salem, H. A. E. A., Morphopathological and Biochemical Changes Induced by Cisplatin as Anticancer Drug and The Protective Role of Moringa Leaf Ethanolic Extract and LCarnitine in Rat. Journal of Current Veterinary Research, 20191 (1): p. 94-102. 